\title{
SUMMARY OF THE FIFTH SCIENTIFIC CONFERENCE EPIMILITARIS 2017 ENTITLED “UNIFORMED AND CIVIL MEDICAL SERVICES AGAINST CONTEMPORARY HAZARDS", RYN (POLAND), 3-5 APRIL 2017
}

\author{
Michał MADEYSKI \\ Military Institute of Aviation Medicine, Science Organization Division, Warsaw, Poland
}

Source of support: Own sources

Author's address: M. Madeyski, Military Institute of Aviation Medicine, Science Organization Division, Krasińskiego 54/56 Street, 01-755 Warszawa, Poland, e-mail: mmadeyski@wiml.waw.pl

On 3-5 April current year, the Fifth Scientific Conference EpiMilitaris 2017 entitled "Uniformed and civil medical services against contemporary hazards" was held. The "EpiMilitaris" cycle conferences are held on a regular basis to gather people whose work or duty is associated with counteracting the CBRN ( Chemical, Biological, Radiological, Nuclear) hazards. The keynote this year was exchange of experience and considerations regarding cooperation of military and civil services against contemporary hazards, both the ones related with natural disasters and with human activity. The conference was organized by: Epidemiological Response Center of the Armed Forces of the Republic of Poland (CRE SZ RP), Defense Communities Movement Association, Disaster Medicine and Emergency Care Facility of the Jagiellonian University - Collegium Medicum, Military Institute of Hygiene and Epidemiology in Warsaw and the Bureau of the Chief Medical Officer of the Slovak Armed Forces. It should be emphasized that the conference has been enjoying great interest among international experts from day one, which is confirmed by the attendance of numerous representatives of US and Slovak Armies.

During the conference, two main areas of interest could be noticed: rules and procedures following contamination and methods of monitoring, anticipation and prevention. The representatives of both Polish and foreign services and institutions presented a coherent and unanimous point of view on the above-mentioned issues. It is evident that our procedures are similar and, additionally, there is a hazard information exchange system.

A very interesting speech was given by major Łukasz Krzowski. He presented the possibilities of creating genetically mutated viruses with the use of commercial materials in one's kitchen or bath-

Full-text PDF: http://www.pjambp.com • Copyright @ 2016 Polish Aviation Medicine Society, ul. Krasińskiego 54/56, 01-755 Warsaw, license WIML • Indexation: Index Copernicus, Polish Ministry of Science and Higher Education 
room. Thereby, he showed how easy one can create a dangerous synthetic virus, emphasizing the significant role of hazard monitoring system and the areas that should be covered by such systems.

Early warning systems were covered by $\mathrm{Mr}$. Tony Intrepido from Cubic Global Defense. He presented a concept of a complex CBRN hazards early warning system. IT solutions related with CBRN hazards were also covered in the speeches of the representatives of the Military University of Technology (WAT): Zbigniew Tarapata, PhD, Eng., prof. WAT major Rafał Kasprzyk, PhD, Eng. and Dariusz Pierzchała, PhD, Eng. Their lectures were connected with the project with the acronym of WAZkA, which is currently being implemented by WAT, and the flu virus hazard monitoring and forecasting system named SARNA, which has already been implemented in the Government Center for Security. Both lectures drew great attention of the representatives of uniformed and civil medical services.

In the session devoted to rescue actions, Michat Madeyski, M.Sc. from WIML presented a lecture entitled "Medical evacuation by air - the role of paramedic in cooperation with the crew of a medical evacuation helicopter". The lecture presented the role of a paramedic in proper preparation of a victim for airborne transport and the cooperation with the crew of a medical evacuation helicopter due to handing the patient over to them for transport. Particular attention was paid to non-medical aspects of the cooperation, which are often the key element of a successful evacuation. Also the issues of proper training of paramedics in the field of aerospace medicine basics.

Another interesting speech was given by Mr. Marcin Błeński, who presented rescue actions in hard conditions, such as in high mountains or caves. Presented were examples of some difficult rescue actions and the challenges the rescuers had to deal with, with indication of the essential role of appropriate planning and preparation of such actions. As was highlighted, these elements are essential also in the case of CBRN hazards.
Captain Thomas Lindley Pittman, physician representing the National Guard of the United States, presented the problems related with handling injured victims on contaminated area. He not only pointed out the medical complications related with giving aid, but also the logistic and technical issues related therewith. He indicated that in this kind of situations it is the logistic preparation that often plays the key role in increasing survivability of not only the injured ones, but also determines the security of those staying in the places where the victims are brought.

During the conference the Disaster Medicine and Emergency Care Facility of the Jagiellonian University - Collegium Medicum and CRE SZ RP prepared a simulation of actions related with detecting a biological attack on the area around the conference venue and on the rooms where the participants were gathered. Without announcement, one person (a malingerer) lost consciousness in the room. Thus, a showcase of the services began, including presentation of equipment and procedures both inside and outside the building, deployment of decontamination line and preparation of the persons directly exposed for transport. The showcase was concluded with viewing of the displayed equipment and discussions between the participants and the soldiers who arranged the simulation who, as part of their daily duties, prepare to react to this kind of alarm conditions.

To sum up, it should be stated that the conference proved good preparation of the Polish Armed Forces for acting in the event of a CBRN attack. It covered important issues related to coordination and cooperation of civil services with each other and in joint action with the army. The lectures given by the representatives of the allied armies showed convergence of thinking among us, as well as an increasingly better organization of IT and research systems of the allies. 